\title{
The factors effecting entrepreneurial intention of university students: case of Mongolia
}

\author{
Altanchimeg Zanabazar $^{1 *}$, Sarantuya Jigjiddorj ${ }^{1}$ \\ ${ }^{1}$ Management Department, Business School, National University of Mongolia Ulaanbaatar, \\ University Street 1, Ulaanbaatar, Mongolia
}

\begin{abstract}
Small and medium sized businesses with entrepreneur orientation have been developing rapidly creating wealth for the nations and often become large global enterprises. The researches on the entrepreneur intention, entrepreneur education, attitude as well as the factors affecting to them are getting popular. Simultaneously, the study on whether the university is nurturing the entrepreneur intention, attitude or boosts students' willingness starting their own businesses has been remaining an interesting topic. The current study aimed at researching various factors affecting the entrepreneur intention, attitude of the students, subjective norms, entrepreneur education, and perceived behaviour control using sample survey involving 568 university students. The survey results demonstrated that the personal attitude had an influence on entrepreneur intention and the participants expressed their willingness starting their own businesses having an awareness on prospective challenges and opportunities. The determinants such as subjective norms and perceived behaviour control had both positive impacts on becoming an entrepreneur; however, an entrepreneur education demonstrated a slight impact in entrepreneur intention.
\end{abstract}

Keywords: small and medium sized businesses, entrepreneurial intention, university students, entrepreneur education

\section{Introduction}

An entrepreneurship is valued as a respectable strategy for the national development of a country and the start-up businesses have been supported and reflected in the government policies of the countries around the world. Researchers considered an entrepreneurship as a necessary component for development of country that enables achieving an adequate economic growth and serves as a driving force of the development [1].

An encouragement of entrepreneurship has numerous benefits like an increase of job opportunities, the reduction of the dependence on a single industry, an enhancement of capital flow that improves the business environment, an increase of prospective businesses, use of outsourcing to provide effective operations and development of new ideas and innovation. Moreover, it is regarded as a booster of social changes through creating new products and

\footnotetext{
*Corresponding author: sarantuyaj@gmail.com, altanchimegz@num.edu.mn
} 
services that contribute to changing old technologies and promoting green technologies that is compatible for the millennium we live at the present time.

Venture creation is a significant source of employment for all countries regardless the development level [2]. While technology and innovation-based start-up companies have been established in recent years in Mongolia, unemployment among higher education graduates still exist and become one of the unsolved social problem. Hence, the universities and colleges' role in addressing emerging needs for improvement of entrepreneur education and teaching curriculum at colleges, preparation of human resources with entrepreneurship mind is crucial.

Objective of the current study aimed at studying correlation between entrepreneur intention and attitude, subjective norm, perceived behaviour control, and entrepreneur education.

\section{Literature Review}

The studies provided in different countries to identify the factors affecting an entrepreneurial intention.

According to the earlier studies it is frequently studied from the perspectives of personal psychological factors in relation to personal traits and behaviour, later scholars started giving a significance inclusion of other demographic factors like age, origin, religion, level of education and employment.

According to Ajzen [3] intentions to perform behaviours can be predicted and attitudes toward behaviour. Therefore, it can be concluded that personal outlook, attitude and close personal associates have a significant influence on an entrepreneur intention. An entrepreneur intention is a personal intent and an intellectual process towards to implementation of the goals [4].

Becoming an entrepreneur is a voluntary, sensible decision and the entrepreneur decision making is explained by entrepreneur intention model. Thus, an entrepreneur intention can be considered as an element of recognizing an entrepreneur behaviour performing and an intention to perform the behaviour depends on the personal attitude.

Historically, various theories and models have proposed in by different scholars like 'entrepreneur event' [5], 'implementing entrepreneur ideas' [6], "theory of planned behaviour' [3], 'an attitude approach to the prediction of entrepreneurship' [7], 'Entrepreneur intentions' [8], and "Competing model of entrepreneurial intentions" [9].

"Theory of planned behaviour" proposed by Azjen in 1991, applied in similar studies more frequently, explained thoroughly factors affecting behavioural intentions intensified researches in entrepreneur intentions and has been applied as the key theory.

Theory of planned behaviour. As stated previously the current concept is widely applied in entrepreneur intention research that is based on the concept 'theory of reasoned action' proposed by Ajzen and Madden. An intention to perform and actual performance have been considered as factors that are strongly correlated and indicates the behaviour. An intention expresses the motivation to perform the certain behaviour and a strong intention increases the probability of performing the behaviour. Three interrelated determinants are used for explaining the intention. 


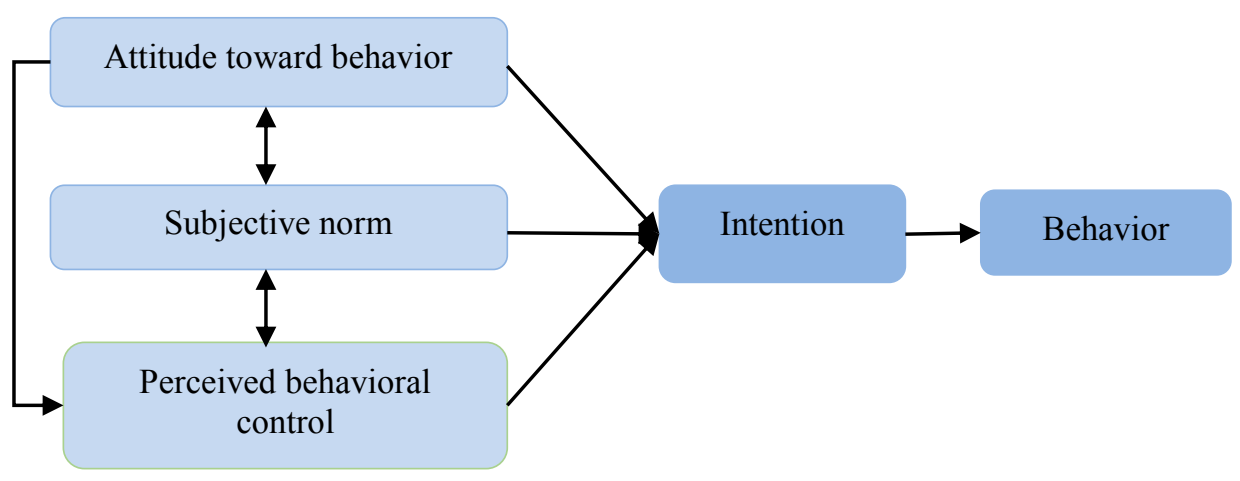

Fig. 1. Model by theory of planned behaviour

Source: [3].

Attitude toward behaviour- the degree to which performance is positively or negatively valued. The outcome of the performance can be determined by the positive or negative experience [10]. An attitude is determined by a certain outcomes, behaviors towards to a certain performance and personal skill, personality can influence it. Personality includes numerous factors like risk taking skill, and goal orientation etc,

Subjective norm - the state can be explained by attitude, beliefs and perceptions of people surrounding an individual. People develop beliefs on what is acceptable or not acceptable and these beliefs shape one's perception of behaviour and intention to perform or not. If the social view is positive towards to the entrepreneur intention increases or if the perception is negative the intention declines [10].

Perceived behaviour control - refers to the person's belief that the performance of behavior is under his control. In other words, it is a perception on whether it is easy or complicated performs certain behaviour. 'Perception' can be determined by the past experiences, ability to overcome forthcoming challenges [11]. More people get experienced and obtain essential knowledge, skills become motivated in performing the behavior.

Entrepreneurial education - Bakri and Mehrez [12] and del Rio-Rama et al. [13] discussed that college education played a significant influence in attitudes toward entrepreneur intention over roles models. Entrepreneurship education is also assumed enhancing among students increasing awareness of entrepreneurship as another career path to employment [14], Laspita, Patzelt, as they have a solid knowledge on business administration.

In the current research we aimed at revealing the interrelationship between entrepreneur education background and entrepreneur intention in relation to the theory of planned behaviour. Entrepreneur education supports the entrepreneurs to perform their intentions to do business and develop necessary skills [15]. According to Linan [16] an entrepreneur education increases the intent of becoming entrepreneur. Entrepreneur education enables entrepreneurs developing key skills for managing the business. In selecting the model of the current study both theory of planned behaviour by Ajzen and model of entrepreneurial intention by Shapero and Sokol are considered with inclusion of a new determinant entrepreneur education as it is demonstrated below. 


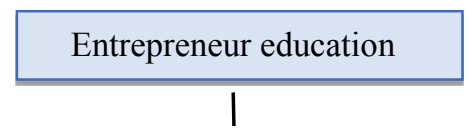

$\mathrm{H} 4$
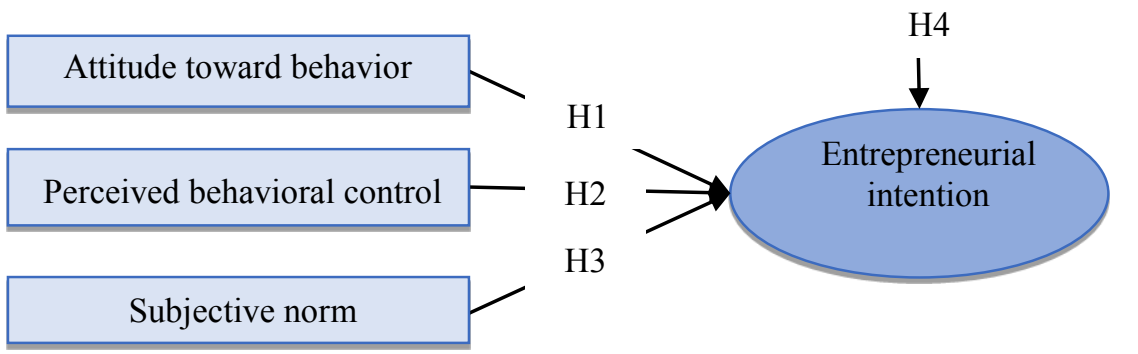

Fig. 2. Model for the study

Source: Authors.

\section{Research hypothesis:}

H1: An attitude toward behaviour positively influences to the entrepreneur intention.

$\mathrm{H} 2$ : Subjective norm positively impacts in the entrepreneur intention.

H3: Perceived behavioural control has a positive impact to the entrepreneur intention.

H4: Entrepreneur education has a positive effect on the entrepreneur intention of the students.

\section{Research Methodology}

The research embraces a quantitative method to empirical support for the hypothesis. To study the how attitude toward behaviour, perceived behavioural control and subjective norms and entrepreneur education have an impact in entrepreneurial education we carried out survey among the Business School students who attended the subject in entrepreneurship in the academic year 2018-2019 between May-June, 2019. A total of 577 questionnaires were collected and 568 questionnaires considered valid for the analysis. The survey instrument included 22 questions that are grouped in to 22 questions along with the four questions on personal background of the respondents.

\subsection{Background information on the survey participants}

Out of 568 participants 354 or $62.3 \%$ are female and 214 or $37.7 \%$ male students studying in different years of their study. By the year of study, 40 students are studied in their first year, 186 students in their second year, 196 of them continued studying in the third year and 146 of them were the fourth-year students.

For testing relevance for factor analysis for data set, Kaiser-Meyer-Olkin (KMO) measure of sampling adequacy is used. According to KMO indicated .845 which means the size of the sample is adequate for the study. In addition, it considered essential to apply the Barlett test of Sphericity to assure that factor analysis can be applied to the data set and the results are shown below in table 1. 
Table 1. KMO and Bartlett's Test

\begin{tabular}{|l|c|r|}
\hline \multicolumn{3}{|c|}{} \\
\hline \multicolumn{2}{|c|}{ Kaiser-Meyer-Olkin Measure of Sampling Adequacy. } & 0.845 \\
\hline \multirow{3}{*}{ Bartlett's Test of Sphericity } & Approx. Chi-Square & 508.535 \\
\cline { 2 - 3 } & df & 10 \\
\cline { 2 - 3 } & Sig. & 0.000 \\
\hline
\end{tabular}

Source: Authors.

Sig. value .000 demonstrated that we can apply the proposed analysis.

Reliability test. For the internal reliability of each factor Cronbach Alpha coefficient is used, which according to [17] a value greater than 0.7 to be considered acceptable. In our case, cronbach a demonstrated value of .880 and considered acceptable (table 2).

$\mathrm{T}$ test is applied to test whether the students' year of study or academic experience has an influence in an entrepreneur intention of the students.

Table 2. Questionnaire Reliability Analysis result

\begin{tabular}{|l|r|r|}
\hline \multicolumn{1}{|c|}{ Factors } & $\begin{array}{c}\text { Number of } \\
\text { questions }\end{array}$ & Cronbach's $\boldsymbol{\alpha}$ \\
\hline Entrepreneurial intention- EI & 4 & .778 \\
\hline Attitude toward behavior - EA & 4 & .839 \\
\hline Subjective norm - SN & 3 & .852 \\
\hline Perceived behavioral control - TPB & 6 & .809 \\
\hline Entrepreneur education- EE & 5 & .810 \\
\hline & 22 & .880 \\
\hline
\end{tabular}

Source: Authors.

The test results are shown in the table 3.

Table 3. Influence of students' year of study in an entrepreneur intention

\begin{tabular}{|l|r|r|r|r|r|}
\hline & $\mathrm{N}$ & \multicolumn{1}{|c|}{ Mean } & \multicolumn{1}{c|}{$\begin{array}{c}\text { Std. } \\
\text { Error }\end{array}$} & \multicolumn{1}{c|}{$\mathrm{t}$} & $\begin{array}{c}\text { Sig. } \\
\text { (2-tailed) }\end{array}$ \\
\hline I year students & 40 & 3.05 & .1285 & 23.671 & .000 \\
\hline $\begin{array}{l}\text { II year } \\
\text { students }\end{array}$ & 186 & 3.23 & .0671 & 49.426 & .000 \\
\hline III year student & 196 & 3.72 & .096 & 63.588 & .000 \\
\hline $\begin{array}{l}\text { IV year } \\
\text { students }\end{array}$ & 146 & 4.17 & .0604 & 66.749 & .000 \\
\hline
\end{tabular}

Source: Authors.

The results show that the students who studied in senior years have an ambition of getting an entrepreneur. $\mathrm{T}$ test applied to identify whether the courses offered for developing entrepreneurship knowledge and skills such as 'Business and Society', 'Business Planning', Project management', and 'Small and Medium Enterprise Management' have an impact in shaping entrepreneur intention results are summarized in table 4. 
Table 4. Correlation between the courses the students enrolled and entrepreneur intention

\begin{tabular}{|l|c|c|c|c|c|c|c|c|}
\hline & \multicolumn{3}{|c|}{ Enrolled the courses } & \multicolumn{3}{c|}{ Did not enroll the } & \multirow{2}{*}{ courses } & \multicolumn{1}{c|}{$\begin{array}{c}\text { Sig. } \\
\text { (2-tailed) }\end{array}$} \\
\cline { 2 - 9 } & $\mathrm{N}$ & Mean & $\begin{array}{c}\text { Std. } \\
\text { Error }\end{array}$ & $\mathrm{N}$ & Mean & $\begin{array}{c}\text { Std. } \\
\text { Error }\end{array}$ & $\mathrm{t}$ & .000 \\
\hline $\begin{array}{l}\text { Business\& } \\
\text { Society }\end{array}$ & 463 & 3.63 & .0380 & 103 & 3.63 & .0931 & 38.776 & .000 \\
\hline $\begin{array}{l}\text { Business } \\
\text { Planning }\end{array}$ & 101 & 3.86 & .0833 & 465 & 3.46 & .0409 & 48.774 & .000 \\
\hline $\begin{array}{l}\text { Project } \\
\text { management }\end{array}$ & 500 & 3.86 & .0863 & 66 & 3.57 & .0395 & 45.998 & .000 \\
\hline $\begin{array}{l}\text { Small \& } \\
\begin{array}{l}\text { Medium } \\
\text { business } \\
\text { management }\end{array}\end{array}$ & 235 & 3.69 & .0520 & 331 & 3.41 & .0487 & 67.233 & .000 \\
\hline
\end{tabular}

Source: Authors.

The students who completed 'Business and Society', 'Project Management', 'Small and Medium Enterprise Management' were highly motivated in becoming entrepreneurs compared to the ones who did not enrol these courses, however 'Business and Society' course had no impact in an entrepreneur intention of the students as there was no difference in the intention if they completed the course or not.

Moreover, test on whether the family members or close people engaged in the business had an influence in students' entrepreneur intention (refer to table 5).

Table 5. Whether the family members or close people engaged in the business have an impact in students' entrepreneur intention

\begin{tabular}{|c|c|c|c|c|c|c|c|c|}
\hline & \multicolumn{3}{|c|}{$\begin{array}{c}\text { Family members or close } \\
\text { people engaged in } \\
\text { business }\end{array}$} & \multicolumn{2}{|c|}{$\begin{array}{c}\text { Family members or } \\
\text { close people not } \\
\text { engaged in business }\end{array}$} & \multirow{2}{*}{$\mathrm{t}$} & \multirow{2}{*}{$\begin{array}{c}\text { Sig. } \\
\text { (2-tailed) }\end{array}$} \\
\cline { 2 - 6 } & $\mathrm{N}$ & Mean & $\begin{array}{c}\text { Std. } \\
\text { Error }\end{array}$ & $\mathrm{N}$ & Mean & $\begin{array}{c}\text { Std. } \\
\text { Error }\end{array}$ & & \\
\hline EI & 384 & 3.85 & .0353 & 182 & 3.18 & .0601 & 87.466 & .000 \\
\hline
\end{tabular}

Source: Authors.

The test results show that the students whose family is engaged in a business had a high intention of becoming entrepreneurs (mean value 3.85) compared to the ones who no family members engaged in the business had low intention (mean value 3.18). From the results it can be concluded that the business family background has an influence in students' entrepreneur intention. Factor analysis presented in table 6. 
Table 6. Pearson Correlation Analysis result

\begin{tabular}{|c|c|c|c|c|c|c|}
\hline \multicolumn{7}{|c|}{ Correlations } \\
\hline & & EI & EA & SN & ТPB & $\mathrm{EE}$ \\
\hline EI & $\begin{array}{l}\text { Pearson Correlation } \\
\text { Sig. (2-tailed) }\end{array}$ & 1 & & & & \\
\hline EA & $\begin{array}{l}\text { Pearson Correlation } \\
\text { Sig. (2-tailed) }\end{array}$ & $\begin{array}{r}.563^{* *} \\
.000\end{array}$ & 1 & & & \\
\hline SN & $\begin{array}{l}\text { Pearson Correlation } \\
\text { Sig. (2-tailed) }\end{array}$ & $\begin{array}{r}.426^{* *} \\
.000\end{array}$ & $\begin{array}{r}.498^{* *} \\
.000\end{array}$ & 1 & & \\
\hline ТРВ & $\begin{array}{l}\text { Pearson Correlation } \\
\text { Sig. (2-tailed) }\end{array}$ & $\begin{array}{r}.473^{* *} \\
.000\end{array}$ & $\begin{array}{r}.417^{* *} \\
.000\end{array}$ & $\begin{array}{r}.324^{* *} \\
.000\end{array}$ & 1 & \\
\hline $\mathrm{EE}$ & $\begin{array}{l}\text { Pearson Correlation } \\
\text { Sig. (2-tailed) }\end{array}$ & $\begin{array}{r}.286^{* *} \\
.000\end{array}$ & $\begin{array}{r}.305^{* *} \\
.000\end{array}$ & $\begin{array}{l}.385^{* *} \\
.000\end{array}$ & $\begin{array}{r}.370^{* *} \\
.000\end{array}$ & 1 \\
\hline
\end{tabular}

Source: Authors.

The results demonstrate that an attitude toward to entrepreneurial intention of business school students $[\mathrm{r}=.563, \mathrm{p}<0.01]$, perceived behavioral control $[\mathrm{r}=.473, \mathrm{p}<0.01]$, subjective norm $[\mathrm{r}=.426, \mathrm{p}<0.01]$ embrace a positive strong correlation, but entrepreneurial education $[\mathrm{r}=.286, \mathrm{p}<0.01]$ revealed a weak correlation.

In the entrepreneurial intention in the study subjective norm presented $[r=.498, p<$ 0.01], and perceived behavioral control $[\mathrm{r}=.473, \mathrm{p}<0.01]$ showed a positive strong correlation, but an entrepreneurial education had moderate correlation.

Attitude toward to entrepreneur to subjective norm showed a strong positive correlation $[\mathrm{r}=.498, \mathrm{p}<0.01]$, but entrepreneur education $[\mathrm{r}=.385, \mathrm{p}<0.01]$, perceived behavioral control $[\mathrm{r}=.324, \mathrm{p}<0.01]$ revealed moderate correlation.

Perceived behavioral control to the attitude to entrepreneur had a positive and strong correlation $[\mathrm{r}=.417, \mathrm{p}<0.01]$, and an entrepreneur education $[\mathrm{r}=.370, \mathrm{p}<0.01]$ and subjective norm $[\mathrm{r}=.324, \mathrm{p}<0.01]$ presented a moderate correlation.

For the confirmation of the hypotheses regression analysis is carried out (refer to table 7).

Table 7. Regression analysis result

\begin{tabular}{|c|r|r|r|r|}
\hline \multicolumn{5}{|c|}{ Model Summary } \\
\hline 1 & \multicolumn{1}{|c|}{ R } & \multicolumn{1}{c|}{ R Square } & $\begin{array}{c}\text { Adjusted R } \\
\text { Square }\end{array}$ & \multicolumn{1}{c|}{ Std. Error of the Estimate } \\
\hline 1 & $.590^{\mathrm{a}}$ & .552 & .546 & 2.5958 \\
\hline
\end{tabular}

a. Predictors: (Constant), EE, EA, TPB, SN

ANOVA $^{\mathrm{a}}$

\begin{tabular}{|l|l|r|r|r|r|c|}
\hline \multicolumn{2}{|l|}{ Model } & Sum of Squares & df & Mean Square & F & Sig. \\
\hline 1 & Regression & 681.542 & 4 & 170.386 & 25.287 & $.000^{\mathrm{b}}$ \\
& Residual & 3793.577 & 563 & 6.738 & & \\
& Total & 4475.120 & 567 & & & \\
\hline
\end{tabular}

a. Dependent Variable: EI

b. Predictors: (Constant), EE, EA, TPB, SN 


\begin{tabular}{|c|c|c|c|c|c|c|}
\hline \multicolumn{7}{|c|}{ Coefficients ${ }^{\mathrm{a}}$} \\
\hline \multirow{2}{*}{\multicolumn{2}{|c|}{ Model }} & \multicolumn{2}{|c|}{$\begin{array}{c}\text { Unstandardized } \\
\text { Coefficients }\end{array}$} & \multirow{2}{*}{$\begin{array}{c}\text { Standardized } \\
\text { Coefficients } \\
\text { Beta }\end{array}$} & \multirow{2}{*}{$\mathrm{t}$} & \multirow{2}{*}{ Sig. } \\
\hline & & B & Std. Error & & & \\
\hline \multirow{5}{*}{1} & (Constant) & 8.765 & .739 & & 11.865 & .000 \\
\hline & EA & .553 & .042 & .512 & 5.987 & .000 \\
\hline & SN & .331 & .053 & .327 & 2.587 & .000 \\
\hline & ТPB & .389 & .030 & .331 & 2.948 & .000 \\
\hline & EE & .234 & .037 & .211 & 1.932 & .000 \\
\hline \multicolumn{7}{|c|}{ a. Dependent Variable: EI } \\
\hline
\end{tabular}

Source: Authors.

As results of the analysis the correlation between entrepreneurial intention and other determinants such as attitude toward behaviour, perceived behavioural control, subjective norm and entrepreneurial education demonstrated $.546 \%$.

Attitude toward to the entrepreneur $[\beta=.512, \mathrm{p}<0.01]$ had a moderate impact, and perceived behavioural control $[\beta=.331, \mathrm{p}<0.01]$, subjective norm $[\beta=.327 \mathrm{p}<0.01]$, and entrepreneurial education $[\beta=.211, \mathrm{p}<0.01]$ demonstrated that they had a low impact (see figure 3).

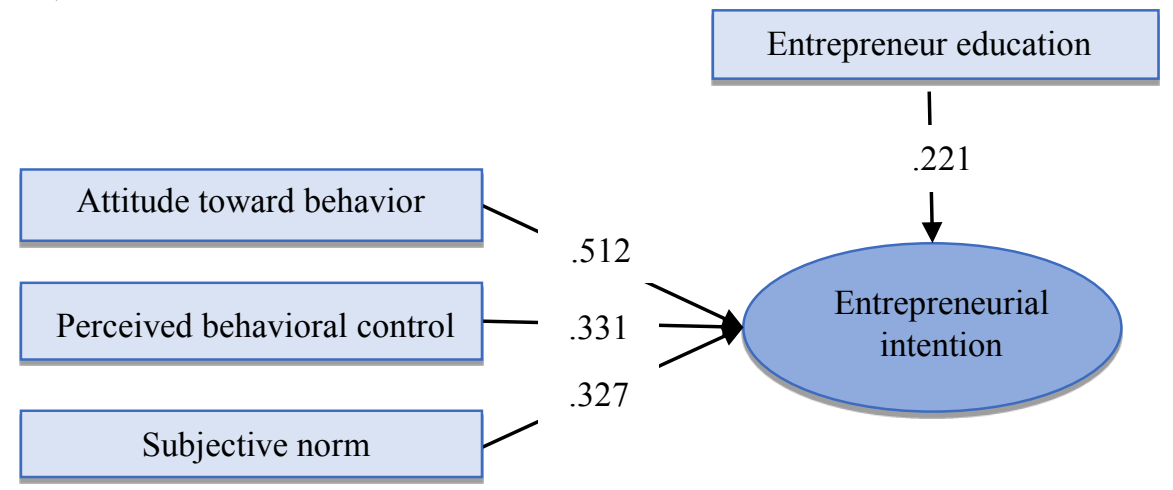

Fig. 3. Research result

Source: Authors.

The hypotheses are all supported as all effects of associated regulator variables (Beta coefficients) are both positive and statistically significant $(\mathrm{p}<0.01)$.

\section{Conclusion and Discussion}

Establishing a new business venture is related with the social skills of the younger generation and their knowledge, skills and attitude are decisive in shaping future of all sectors. Accordingly, numerous studies have been conducted globally in recent years in youth entrepreneur intention, the factors influencing it, entrepreneur education and attitude.

The current study aimed at researching factors influencing in an entrepreneur intention to contribute reinforcement of application of theories and concepts in the case of business students. 
An attitude toward to entrepreneur, subjective norm, perceived behavior control and entrepreneurial education are taken as independent variables, and an entrepreneur intention considered as a dependent variable and to support the proposed hypothesizes various analyses such as reliability test, correlation and regression analysis are carried out.

As correlation analysis show the all factors were correlated with the entrepreneur intention except the entrepreneurial education which indicated low correlation.

According to the results, senior year students' intention to become entrepreneurs was comparatively high. Increase in attitude toward to entrepreneur by one point resulted in the increase of entrepreneur intention by 0.512 (beta) point. In other word, the students are ready to take an opportunity and start their own businesses as they can create numerous advantages.

In overall, the students participated in the survey have a positive attitude toward the entrepreneurship.

Subjective norm also has a positive influence in entrepreneur intention and the survey results show that when family or close people's influence increases by one point, the entrepreneur intention increases by 0.327 (beta) point. The students who are from families who engaged in business had more positive attitude toward entrepreneur intention as they have support and sympathy.

The study revealed that perceived behavioral control has a positive impact in the entrepreneur intention. As the knowledge and skills in performing a private business upgrades the behavior control increases. In the survey, one-point increase of perceived behavioral control resulted in the 0.331 (beta) point in entrepreneur intention. It is clearly seen from the study that despite the potential challenges in performing business, the confidence build upon education experiences contributes to the increase of the entrepreneurial education. According to the survey, the respondent felt confident in overcoming challenges in developing their business ideas.

The survey results demonstrated that more the students complete the courses in entrepreneurship, the entrepreneur intention increases by 0.221 (beta) point. Although the entrepreneur education had a slight impact to the entrepreneur education, the knowledge and education offered at the university influenced positively.

\section{References}

1. W.J. Baumol, R.E. Litan, C.J. Schramm, Good capitalism, bad capitalism and the economics of growth and prosperity. New Haven, CT: Yale University Press (2007)

2. M.R. Uddin, T.K. Bose, Determinants of entrepreneurial intention of business students in Bangladesh. International Journal of Business and Management, 7(24), 128-137 (2012)

3. I. Ajzen, Perceived behavioral control, self-efficacy, locus of control, and the theory of planned behavior. Journal of Applied Social Psychology, 32(4), 665-683 (2002)

4. V.K. Gupta, N.M. Bhawe, The influence of proactive personality and stereotype threat on women's entrepreneurial intentions. Journal of Leadership and Organizational Studies, 13, 73-85 (2007)

5. A. Shapero, L. Sokol, The Social Dimensions of Entrepreneurship. In: C.A. Kent, D.L. Sexton, \& K.H. Vesper (Eds.). Encyclopedia of Entrepreneurship. Englewood Cliffs, NJ: Prentice-Hall, 72-90 (1982)

6. B. Bird, Implementing entrepreneurial ideas: The case for intention. Academy of Management Review, 1(3), 442-453 (1988) 
7. P.B. Robinson, D.V. Stimpson, J.C. Huefner, H. K. Hunt, An attitude approach to the prediction of entrepreneurship. Entrepreneurship Theory and Practice, 13-31 (1991)

8. N.F. Krueger, A.L. Carsrud, Entrepreneurial intentions: Applying the theory of planned behavior. Entrepreneurship and Regional Development, 5, 315-330 (1993)

9. N.G. Boyd, G.S. Vozikis, The Influence of Self-efficacy on the Development of Entrepreneurial Intentions and Actions. Entrepreneurship Theory and Practice, 18(4), 63-77 (1994)

10. L. Kolvereid, Prediction of employment status choice intentions. Entrepreneurship Theory Practice, 21(1), 47-57 (1996)

11. C.W. Scheiner, Fundamental Determinants of Entrepreneurial Behavior. Wiesbaden: Gabler research (2009)

12. A. Bakri, A. Mehrez, Factors influencing entrepreneurial intentions among Arab students. International Journal of Entrepreneurship, 21(3), 1-17 (2017)

13. C. del Rio-Rama et al., Entrepreneurial intentions and Entrepreneurship Education to University students in Portugal. ETechnology, Innovation and Education Journal, 2(7), 1-11 (2019)

14. T.J. Bae et al., The relationship between Entrepreneurship Education and Entrepreneurial intentions: A Meta-Analytical Review. Entrepreneurship Theory and Practice, 38(2), 217-254 (2019)

15. G. Gorman, D. Hanlon, W. King, Some research perspectives on entrepreneurship education and education for small business management: a ten-year literature review. International Small Business Journal: Researching Entrepreneurship, 15(3), 56-77 (1997)

16. F. Linan, Intention-based models of entrepreneurship education. Piccola Impresa / Small Business, 2004(3), 11-35 (2004)

17. J.C. Nunnally, Psychometric theory. $2^{\text {nd }}$ ed. New York: McGraw-Hill (1978) 